\title{
Teachers' Awareness and Utilization of L2 Research Findings: Implications for L2 Teaching in Ondo State, Nigeria
}

\author{
Ogunyemi, Kehinde Olufemi \\ Emmanuel, Isaac Friday \\ Department of Arts Education
}

Adekunle Ajasin University, Akungba Akoko, Ondo State, Nigeria

Doi:10.19044/esj.2020.v16n10p124 URL:http://dx.doi.org/10.19044/esj.2020.v16n10p124

\begin{abstract}
Despite the number of research outputs from various post-graduate students across the country, Nigeria educational system is bedeviled with issues of mass failure in external examinations. This mismatch between students' performances and the jillions of researches which are supposed to solve issues of mass failure among students informs this study. This study, therefore, examined teachers' awareness and utilization of L2 research findings and implication for L2 teaching in Ondo State, Nigeria. Descriptive survey research design was adopted for this study. The simple random sampling technique was used to select forty-three L2 teachers form three local government areas in Ondo State, Nigeria. The instruments used for data collection was a questionnaire entitled Teachers' Awareness and Utilization of L2 Research Findings (TAURFIQ). Two research questions were answered and two hypotheses were tested at 0.05 level of significance. Data were analysed using descriptive statistics and Pearson Product Moment Correlation Coefficient. The study found out that L2 teachers are moderately aware of L2 research findings. Also, the study indicated that there was no significant relationship between L2 teachers' academic qualification and extent of L2 research awareness and utilization. Based on the findings of the study, it was recommended that universities should organize seminars for L2 teachers in order to discuss the applications of the various research findings in the classroom.
\end{abstract}

Keywords: Research awareness, Research Utilization, L2, L2 Teachers

\section{Introduction}

The place of research in capacity building and development cannot be overemphasized. It is critical and pivotal for national growth and development. 
Through the praxis of research, significant contributions have been made that are sine qua non for human growth and development. In view of this, Abbott and Doucouliagos (2004) as cited in Okiki (2013:15) maintain that research is highly significant in "promoting the prosperity of a nation and its citizens ...." Suffice it to say therefore that the world would be much better when we engage in a number of researches.

The term "research" has been misconstrued overtime; quite a number of people have synonymously used it with the term fact finding. In the light of this, it is not uncommon to hear people say "go and make your research" when in the actual sense they were making reference to historical facts. It is however expedient to note that everyone engages in research at one point or the other. Afolabi (2019:201) while explaining this, put it that "when an individual is confronted by a situation, and seeks to find out by investigation, ask questions, analyse situations, sorts and probably make inference", the person is actually carrying out a research. The end-products of any research processes are solutions.

Governments across different geo-space, Nigeria government inclusive, are not oblivious of the wonders research can do when they saddled their universities with the responsibilities of conducting researches and these have been going on for a long period. Apart from the university lecturers, thousands of undergraduates as well as postgraduate students engage in researches yearly and one may want to conclude that the various educational problems in Nigeria would have been researched into. It is however, lugubrious that the various issues confronting Nigerian educational system persist (Fakeye \& Ogunyemi, 2017).

Annually, Nigerian government continues to decry the mass failure of secondary school students in both internal and external examinations, most especially in English language. The English language, no doubt, occupies an exalted position in the Nigerian educational settings. No wonder, Nigerian government made some policy statements regarding it. Nigeria Policy on

Education (2004) states that

a. At the elementary level, usually six years, each child must study two languages, namely his mother tongue (if available for study) or indigenous language of wider communication in his area of domicile and English language.

b. At junior secondary school (JSS) level, usually for three years duration, the learner must study three languages viz (i) his mother tongue (where it has orthography and literature) or/and indigenous language of wider communication in his area of domicile, (ii) English language and (iii). any of the three major indigenous languages in the country, namely, Hausa, Igbo, and 
Yoruba provided the language chosen is distinct from the child's mother tongue.

c. In Senior Secondary School (SSS), which lasts three years, the child must study two languages; namely an indigenous language and English language.

Gleaning from the language policy above, one would notice that there is much emphasis on the ability to use the English language which is the second language (L2). This is because the L2 plays significant linguistic roles in Nigeria. In Nigeria educational circle, it plays a dominant role as the language of instruction and by extension the target language. The success or failure of formal education, to a large extent, depends on the level of competence of learners in L2 in schools and colleges (Ogunyemi, 2014). Yet, in spite of the level of research outputs from various universities in Nigeria on English as a second language, secondary school students continue to perform woefully in English language external examinations. There seems to be a mismatch between L2 research outputs and students' results. This situation makes one to wonder what the problem is. Since there is an "agent" in between the students and research findings, it would be safer therefore to interrogate Nigeria L2 teachers on what they do with the various "solutions" arrived at through researches.

No doubt, teachers occupy an invaluable position in Nigerian educational settings. According to Adebile (2009:290), "teachers' productivity is an important factor in educational development ...." No meaningful development can take place without the efforts of teachers. They are the implementers of the various educational policies and methods in class, so, if anything is going south, the teachers should be questioned. Since there are no common meeting points for L2 researchers in Nigerian universities and L2 teachers who are supposed to be the one to use the methods in classes, L2 research findings may never be implemented. This is because teachers may not be aware of the various L2 researches emanating from Nigerian universities and this would hamper the implementation of such research findings. This study therefore seeks to find out teachers' awareness and utilization of L2 research findings and implications for L2 teaching in Ondo State, Nigeria.

\section{Statement of the Problem}

Overtime, researchers in Nigerian universities are at their best in proffering solutions to various problems confronting the education sector. Yet, students' results in both internal and external examination every year leaves much to be desired. In 2018, only 17.5 percent of candidates who took part in the Senior School Certificate Examination(SSCE), obtained credit and above in five subjects including English Language and Mathematics. In 2019, 26.08 
percent obtained credit and above in a minimum of five subjects including English Language and mathematics (https://allafrica.com/stories/201903120292.html, 2020). Blame is laid at everyone's doorstep; lazy students, seductive media and technology, ineffective teachers, careless parents and apathetic government amongst others for these poor performances. Since the students' results do not correlate with L2 research outputs from Nigerian universities, it may not be out of place to question teachers' L2 research awareness and their utilization in classrooms. This study seeks to find out teachers' L2 research awareness and utilization of L2 research findings and their implications for L2 teaching in Ondo state, Nigeria.

\section{Research Questions}

The research questions are

1. To what extent are secondary school English language teachers aware of L2 research findings emanating from universities in Ondo State?

2. To what extent do L2 teachers utilize research findings in L2 education?

\section{Research Hypotheses}

H01: There will be no significant relationship between L2 teachers' academic qualification and extent of awareness on L2 research findings.

H02: There will be no significant relationship between L2 teachers' academic qualification and extent of utilization of $\mathrm{L} 2$ research findings.

\section{Methods}

An ex-post facto research design was adopted for the study. This is a research design that seeks to find cause - effect relationships. The population for the study comprises of all L2 teachers in public secondary schools in Ondo state, Nigeria. Through simple random sampling technique, a total of fortythree (43) L2 teachers in secondary schools in Akure South, Akoko North and Akoko South Local Government areas were selected for the study. The fortythree (43) L2 teachers were drawn from rural and urban centres of Akure South, Akoko North and Akoko South respectively. The instrument for the study is a self-constructed questionnaire entitled: Teachers' Awareness and Utilization of L2 Research Findings. The instrument has three sections. The first section seeks basic information from the teachers; the subsequent sections sought information regarding teacher's awareness of L2 research findings and utilization. Items on teacher's awareness of L2 research findings are based on 4-point rating scale while the other section on teacher's utilization of L2 research findings are based on 3-point rating scale. Prior to the administration of the instrument, the test-retest method was used to determine its reliability. It was administered twice to five (5) L2 teachers in Ondo West Local 
Government with a three weeks interval. to determine its reliability. The results $r=0.79$ shows that the instrument is reliable. The research questions were answered using descriptive statistics and the Pearson Product Moment Correlation (PPMC).

\section{Results and Discussions}

This section present the analysis and discussion of research findings.

\begin{tabular}{|ccc|}
\hline \multicolumn{1}{|c|}{ Table 1: Frequency } & Distribution showing Respondents' Gender \\
\hline Gender & Frequency & $\%$ \\
\hline Male & 13 & 30.2 \\
Female & 30 & 69.8 \\
Total & 43 & 100.0 \\
\hline
\end{tabular}

The table above revealed that $30.2 \%$ of the respondents were males while $69.8 \%$ were females.

Table 2: Frequency Distribution showing Respondents' Academic Qualifications

\begin{tabular}{|ccc|}
\hline $\begin{array}{c}\text { Academic } \\
\text { Qualification }\end{array}$ & Frequency & $\%$ \\
\hline OND/NCE & 4 & 9.3 \\
HND/BA.Ed/B.A & 35 & 81.4 \\
MA/ME.d/MA.Ed & 4 & 9.3 \\
Total & 43 & 100.0 \\
\hline
\end{tabular}

The table above revealed that $9.5 \%$ of the respondents had OND/NCE, $81.4 \%$ had First Degree (HND/BA.Ed/B.A) while 9.3\% had Postgraduate Degree (MA/ME.d/MA.Ed).

Table 3: Frequency Distribution showing Teacher's Years of Working Experience

\begin{tabular}{|ccc|}
\hline $\begin{array}{c}\text { Years of Working } \\
\text { Experience }\end{array}$ & Frequency & \% \\
\hline I-5 & 6 & 14.0 \\
$6-10$ & 3 & 7 \\
$11-15$ & 14 & 32.6 \\
$16-20$ & 9 & 20.9 \\
$21-25$ & 11 & 25.6 \\
Total & 43 & 100.0 \\
\hline
\end{tabular}

The table above revealed that $14.0 \%$ of the respondents were within the groupings of 1 and 5 years, while $7 \%$ were within the groupings of $6-10 \%$. $32.6 \%$ of the respondents were within the groupings of $11-15$ years, while $20.9 \%$ were within the groupings of $16-20$ years. Lastly $25.6 \%$ of the respondents were within the grouping of 21-25 years. This implied that the sampled respondents have enough years of working experiences as most of them $(32.6 \%)$ indicated that they have been in service for 11 to 15 years. 


\section{Analysis on Research Questions}

Research Question 1: To what extent are secondary school English language teachers in Ondo state aware of L2 research findings emanating from universities in Ondo state?

Table 4: Teachers awareness of L2 research findings

\begin{tabular}{|c|c|c|c|c|c|c|c|c|}
\hline & $\mathrm{N}$ & $\begin{array}{c}\text { No } \\
\text { awareness }\end{array}$ & $\begin{array}{c}\text { Little } \\
\text { awareness }\end{array}$ & $\begin{array}{l}\text { Moderate } \\
\text { awareness }\end{array}$ & $\begin{array}{c}\text { Great } \\
\text { awareness }\end{array}$ & Mean & $\begin{array}{c}\text { Std. } \\
\text { Deviation }\end{array}$ & Decision \\
\hline $\begin{array}{l}\text { Latest textbooks recommended } \\
\text { for teaching in secondary } \\
\text { schools }\end{array}$ & 43 & $7(16.3)$ & $10(23.3)$ & $15(34.9)$ & $11(25.6)$ & 2.6977 & 1.03590 & Accept \\
\hline $\begin{array}{l}\text { Are you aware of the fact that } \\
\text { GTM is no longer in use for L2 } \\
\text { teaching }\end{array}$ & 43 & $21(48.8)$ & $10(23.3)$ & $7(16.3)$ & 5 (11.6) & 1.9070 & 1.06489 & Reject \\
\hline $\begin{array}{l}\text { Eclectic method of teaching } \\
\text { reading comprehension }\end{array}$ & 43 & $23(53.5)$ & $8(18.6)$ & $8(18.6)$ & $4(9.3)$ & 1.8372 & 1.04495 & Reject \\
\hline $\begin{array}{l}\text { Social media could be used in } \\
\text { teaching comprehension } \\
\text { reading }\end{array}$ & 43 & $5(11.6)$ & $14(32.6)$ & $12(27.9)$ & $12(27.9)$ & 2.7209 & 1.00772 & Accept \\
\hline $\begin{array}{l}\text { The use of Computer assisted } \\
\text { instruction in language teaching }\end{array}$ & 43 & 5 (11.6) & $14(32.6)$ & $12(27.9)$ & $12(27.9)$ & 2.6512 & 1.04389 & Accept \\
\hline $\begin{array}{l}\text { Communicative Language } \\
\text { Approach }\end{array}$ & 43 & 7 (16.3) & $12(27.9)$ & $13(30.2)$ & $11(25.6)$ & 2.9302 & .98550 & Accept \\
\hline $\begin{array}{l}\text { The use of Manageable } \\
\text { feedback in essay writing }\end{array}$ & 43 & $5(11.6)$ & $7(16.3)$ & $17(39.5)$ & $14(32.6)$ & 2.8372 & .97420 & Accept \\
\hline $\begin{array}{l}\text { The use of exit slip in language } \\
\text { teaching }\end{array}$ & 43 & $12(27.9)$ & $15(34.9)$ & $13(30.2)$ & $3(7.0)$ & 2.1628 & .92402 & Reject \\
\hline E-animated instructional mode & 43 & $19(44.2)$ & $6(14.0)$ & $13(30.2)$ & 5 (11.6) & 2.0930 & 1.10871 & Reject \\
\hline $\begin{array}{l}\text { The use of scaffolding in } \\
\text { language teaching }\end{array}$ & 43 & $.9)$ & $13(30.2)$ & $9(20.9)$ & $3(7.0)$ & 1.9302 & .96103 & Reject \\
\hline Valid N (listwise) & 43 & & & & & & & \\
\hline
\end{tabular}

The table above shows the level of L2 research awareness among English language teachers in Ondo state. For the purpose of this study, a mean value of 2.5 is set as a benchmark for decision making. The mean value of 2.5 and above indicates awareness on the aspect of the research while the one below indicates low research awareness. The first item indicates the mean of 2.7 which implied that L2 teachers are aware of the various researches bordering on L2 textbooks. On the second item on the table, are you aware of the fact that GTM is no longer in use for L2 teaching, the results show that the teachers are not aware of this decision that GTM should be disused in class. The third item with the mean value of 1.84 reveals that majority of the L2 teachers in Ondo state are not aware of the researches conducted on eclectic method of teaching reading comprehension. The next item which sought for L2 teachers' level of awareness on teaching comprehension through social media indicates that they are greatly aware (2.72). In the same manner, the 
results on the use of computer assisted instruction in language teaching reveals that Ondo state L2 teachers are moderately aware of researches in this direction. Mean values of (2.93) on communicative language approach shows that L2 teachers are greatly aware of the researches on this aspect. The results on the item that sought for information on the use of manageable feedback in essay writing indicate that the teachers are greatly aware of the researches on this aspect. The results emanating from the following items: the use of exit slip in language teaching; E-animated instructional mode and the use of scaffolding in language teaching reveal that the respondents have low level of research awareness on these aspects of language teaching.

Research Question Two: To what extent do L2 teachers utilize research findings in L2 education?

Table 5: Showing the extent to which L2 teachers utilize research findings in L2 in Nigeria

\begin{tabular}{|c|c|c|c|c|c|c|c|}
\hline & $\mathrm{N}$ & Not heard & $\begin{array}{c}\text { Heard not } \\
\text { use }\end{array}$ & $\begin{array}{c}\text { Heard and } \\
\text { use }\end{array}$ & Mean & $\begin{array}{c}\text { Std. } \\
\text { Deviation }\end{array}$ & Decision \\
\hline Communicative Language Approach & 43 & $6(14.0)$ & $5(11.6)$ & $32(74.4)$ & 2.6047 & .72832 & Accept \\
\hline $\begin{array}{l}\text { E-animated instructions mode for } \\
\text { comprehension passages }\end{array}$ & 43 & $11(25.6)$ & $22(51.2)$ & $10(23.3)$ & 1.9767 & .70672 & Reject \\
\hline $\begin{array}{l}\text { Using Social Media in Teaching } \\
\text { Comprehension Reading }\end{array}$ & 43 & $7(16.3)$ & $25(58.1)$ & $11(25.6)$ & 2.0930 & .64785 & Reject \\
\hline $\begin{array}{l}\text { Background noise and } \\
\text { comprehension reading }\end{array}$ & 43 & $19(44.2)$ & $20(46.5)$ & $4(9.3)$ & 1.6512 & .65041 & Reject \\
\hline $\begin{array}{l}\text { Teachers Quality and Students' } \\
\text { Performance }\end{array}$ & 43 & $7(16.3)$ & $6(14.0)$ & $30(69.8)$ & 2.5349 & .76684 & Accept \\
\hline New methods of test and assessment & 43 & $10(23.3)$ & $6(14.0)$ & $27(62.8)$ & 2.3953 & .84908 & Reject \\
\hline $\begin{array}{l}\text { The use of Manageable feedback in } \\
\text { essay writing }\end{array}$ & 43 & $8(18.6)$ & $7(16.3)$ & $28(65.1)$ & 2.4651 & .79728 & Reject \\
\hline $\begin{array}{l}\text { The use of exit slip in language } \\
\text { teaching }\end{array}$ & 43 & $22(51.2)$ & $15(34.9)$ & $6(14.0)$ & 1.6279 & .72451 & Reject \\
\hline $\begin{array}{l}\text { The use of Computed assisted } \\
\text { instruction in language teaching }\end{array}$ & 43 & $10(23.3)$ & $21(48.8)$ & $12(27.9)$ & 2.0465 & .72222 & Reject \\
\hline $\begin{array}{l}\text { The use of scaffolding in language } \\
\text { teaching }\end{array}$ & 43 & $19(44.2)$ & $15(34.9)$ & $9(20.9)$ & 1.7674 & .78185 & Reject \\
\hline Valid N (listwise) & 43 & & & & & & \\
\hline
\end{tabular}

Having considered the level of L2 research awareness among L2 teachers in Ondo state, this aspect sought to know the extent to which L2 teachers utilize the various research findings in their classes. The first item on the table with the mean of 2.6 indicates that L2 teachers are aware of the researches on Communicative Language Approach and they use it in their classes. The results on the second item, E-animated instructions mode for comprehension passages, shows that L2 teachers are not aware of the various researches on this aspect and consequently could not use it in their teaching. In the same vein, the third item on the table reveals that L2 teachers do not 
utilize research findings on the use of social media in teaching reading comprehension. On the effects of background noise on comprehension reading, the results indicate that $\mathrm{L} 2$ teachers are not aware and do not utilize the findings of the study in their classes. More so, the results on the impact of teachers' quality on the students' performance show that L2 teachers are aware of the various findings on this aspect and do use its findings in classes. Further, the results on the new methods of tests and assessments show that the teachers, despite the fact that they are aware, do not still utilize these in class. It would be recalled that the previous table indicated that L 2 teachers are aware of the various researches on the use of manageable feedback in essay writing; however, the results here indicated that they do not use the findings in their classes. The results on the use of exit slip in language teaching display that L2 teachers in Ondo state are not aware of the findings of the study on the use of exit slip in language teaching and therefore do not utilize in classes. On the use of Computer assisted instruction in language teaching, the results indicate that L2 teachers are yet to utilize its findings in their classes. On a final note, the results on the use of scaffolding in language teaching reveal that L2 teachers in Ondo state are not aware of the research on this aspect and so therefore do not use it in classes. On the whole, the result showed that teachers' level of research awareness on L2 research findings is low and consequently do not use the various solutions arrived at.

\section{Test of Hypotheses}

H01: There will be no significant relationship between L2 teachers' academic qualification and extent of awareness on L2 research findings.

Table 6: Pearson Correlation Co-efficient showing the Relationship between L2 Teachers' Academic Qualification and Extent of Research Awareness on L2 Research Findings

\begin{tabular}{|c|c|c|c|}
\hline & & $\begin{array}{c}\text { Teachers' } \\
\text { L2 Research } \\
\text { Awareness }\end{array}$ & $\begin{array}{c}\text { Teacher's } \\
\text { Academic } \\
\text { Qualification }\end{array}$ \\
\hline \multirow[t]{3}{*}{ Teacher } & Pearson Correlation & 1 & .082 \\
\hline & Sig. (2-tailed) & & .601 \\
\hline & $\mathrm{N}$ & 43 & 43 \\
\hline \multirow[t]{3}{*}{ Academic Qualification } & Pearson Correlation & .082 & 1 \\
\hline & Sig. (2-tailed) & .601 & \\
\hline & $\mathrm{N}$ & 43 & 43 \\
\hline
\end{tabular}

The result indicated that there is no significant relationship between teachers' academic qualifications and the extent of awareness on L2 research findings.. The table above showed a PPMC correlation of 0.082 at a $\mathrm{p}$ value of 0.601 . This implies that there is no significant relationship between Teachers' L2 research awareness and Teachers' qualification. Irrespective of 
the fact that most of the teachers are qualified for the job, 9.5\% had OND/NCE 81.4\% had First Degree (HND/BA.Ed/B.A) while 9.3\% had Postgraduate Degree (MA/ME.d/MA.Ed), yet, they are not really updating knowledge in their various disciplines and this is reflecting on their products. The result proved that the observed variations in the table above were not significant. This implied that there is no significant relationship between L2 teachers' academic qualification and extent of awareness on L2 research findings. The findings confirmed the formulated null hypothesis 1 .

H02: There will be no significant relationship between L2 teachers' academic qualification and extent of implementation of L2 research findings.

Table 7: Pearson Correlation Co-efficient showing the Relationship between L2 Teachers' Academic Qualification and Extent of Implementation of L2 Research Findings

\begin{tabular}{|cl|r|r|}
\hline & \multicolumn{1}{|c|}{$\begin{array}{c}\text { Teacher's } \\
\text { Academic } \\
\text { Qualification }\end{array}$} & $\begin{array}{c}\text { Implementations of } \\
\text { L2 Research } \\
\text { Findings }\end{array}$ \\
\hline Academic Qualification & Pearson Correlation & 1 & .069 \\
& Sig. (2-tailed) & 43 & .660 \\
& $\mathrm{~N}$ & .069 & 43 \\
\hline Implementation & Pearson Correlation & .660 & 1 \\
& Sig. (2-tailed) & 43 & 43 \\
& $\mathrm{~N}$ & & \\
&
\end{tabular}

The result in the table above indicated that there is no significant relationship between L2 teachers' academic qualification and extent of implementation of L2 research findings. The table above showed a PPMC correlation of 0.069 with a $\mathrm{p}$ value of 0.661 . This result implied that teachers' academic qualifications do not have significant influence on the extent of implementation of L2 research findings. This implied that there is no significant relationship between L2 teachers' academic qualification and extent of awareness on L2 research findings. The findings confirmed the formulated null hypothesis 2 .

\section{Implication of the Findings to L2 Teaching}

Research is considered an important aspect of educational settings. The results of this study have some implications for the English language teachers as well as the curriculum planners. Based on the findings of the study, it is clear that L2 research awareness is central to L2 research implementations. The study revealed that L2 teachers are moderately aware of the various L2 research findings in Ondo State. This implies that quite a number of research findings are not implemented because the L2 teachers who are supposed to implement them are not adequately informed. The implication of this is that there may be no change in student's English language achievement due to L2 
teachers' ignorance of the various solutions available for the language learning problems being faced by the students.

\section{Conclusion}

The conduct, publication and utilization of research findings are of great value in higher institutions of learning across the world. When appropriately implemented, such research findings are capable of bringing about improved performance by the students and general improvement in educational practices. From the findings of this study however; it was revealed that L2 teachers' level of research awareness is not encouraging and this is largely responsible for low performances of students in external examinations. The study also revealed that teachers' academic qualifications have no significant influence on the implementation of research findings. This indicates that teachers are generally not aware of L2 research findings and consequently do not make use of such findings in the classroom. Hence researchers should devise better means of disseminating their research findings. Other researchers should also consider replicating this study using a larger sample size. This is necessary to find out teachers' level of L2 research awareness in other parts of the country.

\section{Recommendations}

Based on the findings of the study, the following recommendations were made:

* that L2 teachers consciously update knowledge on their area of specialization from time to time on every aspects of language teaching;

* hosting universities should organize seminars for L2 teachers in order to discuss the applications of the various research findings in the classroom;

* the hosting university should make a list of new research findings to L2 teachers from time to time;

a body be created that will serve as an intermediary between L2 teachers and researchers (lecturers mainly) that will be in charge of updating L2 teachers on new research findings.

\section{References:}

1. Abbott, M., \& Doucouliagos, H. (2004). Research output of Australian universities. Education Economics Journal, 12(3), 265-271

2. Adebile, R. F. (2009). Curriculum implementation and re-training of teachers in English language: Pre-conditions for functional Nigerian educational system. International Multi-Disciplinary Journal, Ethiopia,3 (2), ISSN 1994-9057 (Print) ISSN 2070-0083 (Online) 
3. Afolabi, S. S. (2019). Awareness about and implementation of research findings on mathematics education among teachers in selected schools in Ibadan, Nigeria. Makerere Journal of Higher Education, 10(2), 201-212

4. Fakeye, D. O. \& Ogunyemi, K. O. (2017). Issues in language: The Nigerian perspective. In Falaye, F. V. \& Adegbile, J. A. (Eds) Issues in Curriculum and Language Education. 197-208. Ibadan: Ibadan University Press.

5. Federal Republic of Nigeria. (2004). National Policy on Education. Lagos: NERDC

6. Ogunyemi, K. O. (2014) Extent of implementation of the national language policy at the basic education level in Ogun state, Nigeria. Akungba Journal of Research in Education 2(1), 139-153.

7. Okiki, O. C. (2013). Information literacy skills and availability of information resources as factors influencing research productivity of academic staff of federal universities in Nigeria. PhD Thesis, University of Lagos, Nigeria. 